\title{
MEMBAYANGKAN BANDUNG DALAM SATU DASAWARSA PASCA-KONFERENSI ASIA AFRIKA: KONEKTIVITAS GLOBAL, MODERNITAS, DAN PERUBAHAN SOSIAL (1955-1965)
}

\author{
IMAGINING BANDUNG IN A DECADE AFTER THE ASIAN-AFRICAN \\ CONFERENCE: GLOBAL CONNECTIVITY, MODERNITY, AND SOCIAL \\ CHANGES (1955-1965) \\ Ayu Wulandari \\ Alumnus S1 Ilmu Sejarah, Fakultas Ilmu Budaya, Universitas Gadjah Mada \\ Jl. Sosio Humaniora, Bulaksumur, Yogyakarta 55281 \\ wulandrayu.99@gmail.com
}

DOI: 10.36424/jpsb.v7i2.273

Naskah Diterima: 20 Juli 2021 Naskah Direvisi: 28 Agustus 2021

Naskah Disetujui: 06 September 2021

\begin{abstract}
Abstrak
Pelaksanaan Konferensi Asia Afrika (KAA) pada 1955 di Bandung memiliki dampak yang sangat luas. Bagi Indonesia, KAA memberikan warisan posisi yang terhormat dalam diplomasi pascakolonial, khususnya di Asia dan Afrika atau "Dunia Ketiga". Namun demikian, dampak konferensi ini tidak hanya dirasakan oleh Indonesia secara umum. Konferensi ini juga mengubah citra Bandung yang merupakan kota penyelenggaraan konferensi. Oleh karena itu, kajian ini membahas kondisi Kota Bandung dan masyarakatnya pasca-KAA. Kajian ini disusun menggunakan metode sejarah yang memanfaatkan arsip, majalah, dan surat kabar sebagai sumber primer. Hasil kajian ini menunjukkan bahwa pasca-KAA, Bandung bertransformasi menjadi "Kota Konferensi Internasional", diikuti oleh pembangunan dan terbentuknya citra Bandung sebagai kota politik global sehingga kota ini juga menjadi ruang terkoneksinya aktor politik global. Ironisnya, prestasi dan modernitas ini justru diikuti oleh perubahan sosial yang menunjukkan sisi lain Kota Bandung. Berbagai masalah sosial dan ekonomi meluas di kota ini mulai dari kemiskinan hingga degradasi moral.
\end{abstract}

Kata kunci: Konferensi Asia Afrika, Kota Bandung, Kota Konferensi Internasional, Modernitas, Perubahan Sosial.

\begin{abstract}
The holding of the Asian-African Conference $(A A C)$ in 1955 in Bandung had a very big impact. For Indonesia, the AAC gave a legacy of an honorable position in post-colonial diplomacy, particularly in the Asia and Africa region or known as the "Third World". However, the impact of this conference was not only felt by Indonesia in general. But
\end{abstract}


this conference also changed the image of Bandung, which is the city where the conference is held. Therefore, this study discusses the condition of Bandung City and its people after the AAC. This study is compiled using historical methods with archives, magazines, and newspapers as primary resources. The results of this study indicate that after the AAC, Bandung was transformed into an "International Conference City", followed by the development and the increase of Bandung's image as global political city so this city also became as connected space for global political actors. Ironically, these achievements and modernity were actually followed by social changes that showed a different side of Bandung City. Many social and economic problems were widespread in this city, ranging from poverty to moral degradation.

Keywords: Asian African Conference, Bandung City, International Conference City, Modernity, Social Changes.

\section{PENDAHULUAN}

"Dengan gilang-gemilang Bandung keluar dari udjian jang maha berat. Untuk beberapa waktu mendjadi tuan-rumah dari 29 negara di Asia-Afrika. Sebagai warga-negara kita bangga melihatnja. Penerimaan tamu-tamu jang rapih dan ramah-tamah, penjelenggaraan konperensi jang memuaskan, pendjagaan keamanan jang tertib dan correct, lalu lintas jang teratur, pendek kata: setiap petugas mendjunjung tinggi kehormatan negara. Itulah Bandung, jang sekaligus mendjadi buah bibir negaranegara di seluruh dunia. Bandung, a lovely city, kata tamu-tamu. Bandung, the capital of Asia and Africa, kata Nehru. Bandung memasuki buku sedjarah dengan megahnja..."

(Anonim, Mei 1955:221)

Kutipan teks di atas merupakan gambaran megahnya Bandung sebagai tuan rumah Konferensi Asia Afrika (KAA) pada 1955. Jauh sebelum KAA, Bandung sebenarnya telah megah, modern, dan dikenal luas. Kota ini pernah menjadi primadona pada masa kolonial Hindia Belanda. Hal ini mengacu pada banyaknya sanjungan yang ditujukan kepada Bandung. Mumford (2002) sebagaimana dikutip oleh Nurwulandari dan Kurniawan (2020:15) menyebutkan bahwa pada 1928 misalnya, Bandung dijuluki sebagai salah satu kota yang paling nyaman dan menyenangkan untuk rekreasi dan olahraga.

Bandung juga menyita perhatian Pemerintah Kolonial Hindia Belanda. Lokasinya yang strategis, nyaman, dan sejuk menarik minat Pemerintah Kolonial untuk memanfaatkan Kota Bandung sebagai ibukota Priangan pada 1864 dan menggantikan 
posisi Cianjur (Nurwulandari dan Kurniawan, 2020:16-17). Bandung juga pernah menjadi pusat pertahanan militer yang ditandai dengan pemindahan pabrik senjata Artellerie Inrichringen yang sebelumnya berada di Surabaya (Suganda, 2011:3).

Selain menarik untuk dijadikan pusat pemerintahan, Bandung juga menawarkan destinasi wisata yang cukup menjanjikan. Pada paruh pertama abad ke-20, Bandung menjadi salah satu kota favorit para wisatawan yang datang ke Hindia Belanda. Kota ini mendapat berbagai julukan seperti Parijs van Java, Geneve van Java, Montpeiller of Java, hingga Switzerland van Java (Nurwulandari dan Kurniawan, 2020:18). Pemerintah Kolonial Hindia Belanda juga sempat memiliki wacana untuk menjadikan Bandung sebagai ibukota Hindia Belanda, namun upaya ini tidak sempat terwujud karena kondisi politik kemudian berubah dengan sangat cepat terutama ketika Jepang mulai melakukan ekspansi militer.

Pesona Kota Bandung tidak berakhir meskipun kekuasaan berganti secara cepat pada 1940an. Ketika Indonesia merdeka, Bandung menjadi salah satu kota yang mengisi narasi sejarah revolusi melalui peristiwa Bandung Lautan Api. Peristiwa ini sempat membuat Bandung porak poranda yang seakan mengantarkan kota ini menjadi kota mati. Namun pada 1955, Bandung kembali menorehkan catatannya dalam lembaran sejarah. Dengan menjadi tuan rumah Konferensi Asia Afrika (KAA), Bandung kembali dikenal oleh masyarakat internasional. Bandung kemudian menjadi kota yang cukup penting dalam diskursus politik internasional, terutama bagi gerakan antikolonialisme dan antiimperialisme. Citra ini masih bertahan setidaknya sampai satu dasawarsa kemudian.

Sebelumnya, telah ada berbagai kajian mengenai sejarah kota Bandung dan peristiwa-peristiwa yang pernah terjadi di dalamnya. Berbagai kajian yang sudah diterbitkan antara lain memoar Roeslan Abdulgani (2011) yang berjudul The Bandung Connection: Konperensi Asia Afrika di Bandung Tahun 1955. Memoar ini merupakan salah satu sumber terbaik yang membahas KAA dari persiapan hingga pelaksanaannya. Dalam beberapa hal, Abdulgani (2011) menyinggung kondisi Bandung seperti mengenai masalah keamanannya. Sayangnya, Abdulgani (2011) tidak menitikberatkan kajian ini pada bagaimana kondisi Bandung pasca penyelenggaraan KAA. Kemudian, 
kajian lain yang membahas KAA seperti Konferensi Asia-Afrika 1955: Asal Usul Intelektual dan Warisannya bagi Gerakan Global Antiimperialisme karya Wildan Sena Utama (2011) pun tidak menyinggung kondisi Bandung pasca penyelenggaraan KAA. Kemudian mengenai sejarah Kota Bandung, Rusnandar (2010) dalam tulisannya yang berjudul Sejarah Kota Bandung dari "Bergdessa" (Desa Udik) Menjadi Bandung “Heurin Ku Tangtung” (Metropolitan) telah mengkaji perkembangan Kota Bandung dari masa ke masa. Sayangnya, periode 1950 hingga 1960an yang menjadi periode penting dalam perkembangan Kota Bandung menuju kota metropolitan justru absen dari pembahasan. Kajian lainnya adalah Geliat Kota Bandung: Dari Kota Tradisional Menuju Modern karya Achdian, peny. (2020). Sama seperti kajian sebelumnya, kajian ini mengkaji perkembangan Bandung dari masa ke masa dengan menitikberatkan pada kaitannya dengan keberadaan Bank Indonesia. Sayangnya, kajian ini juga tidak secara detail membahas pengaruh KAA terhadap perkembangan Kota Bandung sepuluh tahun ke depan.

Berdasarkan tinjauan terhadap beberapa karya di atas, dapat disimpulkan bahwa sejauh ini narasi akademik yang menggambarkan kondisi Bandung pasca-KAA belum dihadirkan. Kekosongan narasi ini menimbulkan pertanyaan, bagaimana citra dan kondisi Bandung pasca-KAA diselenggarakan? Sebab usai KAA, Bandung menjadi kota langganan bagi berbagai pertemuan yang cukup mempengaruhi iklim politik internasional. Pertanyaan ini semakin kuat dengan hadirnya kajian dari de FreytasTamura (September 2009) yang menempatkan Brussels dan Paris sebagai "kota politik global" (global political city) berdasarkan pertemuan-pertemuan internasional yang pernah diselenggarakan di kedua kota ini.

Meskipun berbeda dengan Brussels dan Paris yang didalamnya terdapat kantor perwakilan negara lain atau kantor organisasi internasional, Bandung yang tidak memiliki fasilitas tersebut tetap menjadi salah satu kota penyelenggara pertemuan besar, bahkan menjadi "pusat" bagi jaringan politik transnasional yang menentang kolonialisme. Mengenai konsep kota politik global atau global political city, konsep ini tidak secara kaku diartikan sebagai kota yang kebijakannya atau pemerintahnya terlibat dalam urusan internasional. Kota politik global juga dapat dimaknai sebagai kota yang 
menjadi tempat di mana pertemuan internasional diselenggarakan atau kota yang menjadi tempat bagi pengambilan keputusan oleh para aktor politik internasional.

Berdasarkan latar belakang di atas, maka kajian ini membahas citra, kondisi, hingga perubahan sosial di Bandung dalam satu dasawarsa pasca-KAA (1955-1965) dengan menggunakan pendekatan global political city. Kajian ini melihat secara detail bagaimana Bandung bertransformasi menjadi ruang terhubungnya para aktor politik global. Persoalan mengenai apakah modernitas ini dapat diakses oleh masyarakat lokal atau tidak juga menjadi bagian dari kajian ini.

Lebih dari itu, kajian ini mengajukan tesis dimana peristiwa atau momen diplomatik dapat menjadi akar dari perkembangan dan perubahan suatu wilayah, baik perubahan dalam hal citra (image), pembangunan fisik, maupun perubahan sosial. Karenanya, kajian ini juga hadir sebagai alternatif dalam mengkaji sejarah kota yang tidak melulu berakar dari kondisi internal kota itu sendiri, melainkan juga memperhatikan faktor-faktor penting seperti peristiwa diplomatik.

\section{METODE PENELITIAN}

Penelitian ini dilakukan dengan menggunakan metode penelitian sejarah. Metode ini meliputi pemilihan topik, pengumpulan sumber atau heuristik, kritik sumber atau verifikasi, interpretasi, dan diakhiri dengan tahap penulisan atau historiografi (Kuntowijoyo, 2013:69). Penelitian ini menggunakan sumber-sumber berupa arsip, majalah, surat kabar, serta sumber-sumber pustaka seperti buku dan jurnal ilmiah. Sumber-sumber berupa arsip diperoleh dari ANRI (Arsip Nasional Republik Indonesia).

Sementara mengenai majalah dan surat kabar, penulis memperolehnya dari Perpustakaan Nasional dan beberapa media yang dapat diakses secara daring. Untuk sumber pustaka, berhasil diperoleh di berbagai perpustakaan mulai dari Perpustakaan Nasional, Perpustakaan Universitas Gadjah Mada, dan lain-lain. Tahap selanjutnya ialah kritik sumber atau verifikasi, yang dilakukan dengan membandingkan isi satu sumber dengan yang lainnya agar dapat menemukan informasi yang valid dan dapat dipercaya. Sumber-sumber yang telah diseleksi ini kemudian memasuki tahap interpretasi, dan akhirnya disusun menjadi kajian yang kronologis, rinci, dan dapat dipercaya. 


\section{PEMBAHASAN}

Memahami kondisi dan perkembangan Kota Bandung dan masyarakatnya pada satu dasawarsa pasca penyelenggaraan Konferensi Asia Afrika (KAA) merupakan hal yang cukup kompleks. Untuk memahami kondisi ini, maka penting bagi kita untuk kembali mengenang penyelenggaraan KAA 1955 dan suasana Bandung pada saat yang sama. Bagaimanapun, kondisi yang dibentuk pada tahun 1955 menjadi akar dari bagaimana kemudian Bandung berkembang pada tahun-tahun selanjutnya. Pembahasan selanjutnya menekankan pada citra Bandung sebagai kota konferensi internasional hingga membuka sisi lain Kota Bandung yang sangat berlawanan dengan segala kemajuan yang ada.

\section{Tuan Rumah Konferensi Asia Afrika (KAA) 1955}

Tahun 1950an merupakan masa dimana panggung politik internasional diwarnai oleh suasana Perang Dingin, sebuah kontestasi politik sekaligus perebutan pengaruh antara Blok Barat (dipimpin Amerika Serikat) dan Blok Timur (dipimpin Uni Soviet). Dinamika ini menciptakan polarisasi yang menembus batas-batas geografis dan seakan membagi dunia menjadi dua kubu yang saling bertentangan. Perang Dingin juga berpotensi menciptakan konflik hingga kolonialisme dalam bentuk baru di kawasan Asia dan Afrika.

Kekhawatiran semakin meningkat ketika menyadari bahwa negara-negara Asia dan Afrika tengah memasuki gelombang dekolonisasi. Bagaimanapun, dekolonisasi ini “...membuat para pemimpin berbagai negara pascakolonial di Asia dan Afrika berhadap-hadapan langsung dengan dua protagonis utama Perang Dingin, Amerika Serikat dan Uni Soviet" (Utama, 2017:63). Kondisi ini mengantarkan negara-negara Asia dan Afrika pada suatu kesadaran baru untuk membentuk solidaritas Asia-Afrika. Solidaritas ini sebenarnya bukan sesuatu yang baru. Solidaritas ini pernah digaungkan oleh mahasiswa Indonesia yang berada di luar negeri melalui dua titik, yakni Bierville (Prancis) dan Brussel (Belgia) pada tahun 1926 dan 1929 (Abdulgani, 2011:19). Solidaritas ini kemudian jelas terlihat melalui KAA 1955 yang penyelenggaraannya diusulkan oleh Ali Sastroamidjojo yang pada saat itu menjabat sebagai Perdana Menteri 
Indonesia. Konferensi ini dilaksanakan sejak tanggal 18 sampai 24 April 1955, bertempat di Kota Bandung, Jawa Barat.

Konferensi ini juga berhasil menarik perhatian dunia internasional. Suryocondro, pegawai Kedutaan Besar Republik Indonesia di Washington D. C., pernah melampirkan beberapa pers Barat yang memberikan reaksinya terhadap KAA, antara lain Business Week hingga Time Magazine yang menuduh KAA sebagai ajang pamer kelincahan negara-negara baru hingga menjadi panggung penyebaran komunisme oleh China (ANRI, Januari 1955). Terlepas dari segala perdebatan yang terjadi, KAA telah memberikan tempat terhormat bagi Indonesia di panggung politik internasional. Konferensi ini mendorong Indonesia menjadi "pemimpin" Dunia Ketiga. Presiden Soekarno yang sebelumnya hanya dikenal sebagai Presiden Indonesia pun kemudian lebih dikenal sebagai tokoh Dunia Ketiga. Kemudian, Bandung sebagai kota tuan rumah konferensi juga mendapatkan kehormatan di panggung internasional. Sejak KAA diselenggarakan, Bandung menjadi salah satu kota terpenting dalam diplomasi pascakolonial.

Mohammad Yamin dalam artikelnya yang diterbitkan oleh surat kabar Merdeka sempat menyinggung kemahsyuran Kota Bandung dalam KAA, khususnya dikaitkan dengan pembebasan Irian Barat. Mohammad Yamin dengan tegas menuliskan “...dari Bandung bersinar cahaya kemenangan: merdekalah Irian Barat, tanah air kita di pinggir Samudra Pasifik" (ANRI, April 1955). Pernyataan tersebut setidaknya menunjukkan bahwa bagaimanapun, KAA telah membuat Kota Bandung menjadi salah satu pusat dalam perjuangan politik menghancurkan kolonialisme dan imperialisme. Lebih dari itu, Bandung di kemudian hari menjadi kota yang sangat dikenal di dunia. Karenanya, ada banyak perubahan yang terjadi pada Bandung pasca-KAA.

Sebelum membahas perubahan seperti apa yang terjadi pada Bandung pascaKAA, perlu ditelusuri terlebih dahulu mengenai kondisi dan peran Kota Bandung beserta masyarakatnya dalam KAA. Roeslan Abdulgani ketika mengenang KAA, menyatakan bahwa Bandung dipilih sebagai kota penyelenggaraan konferensi karena iklim dan akomodasinya yang cukup lengkap (Abdulgani, April-Mei 1965:17). 
Terpilihnya Bandung membuat masyarakat setempat sangat bangga, bahwa kota mereka akan menjadi tuan rumah dalam konferensi bersejarah. Sebuah artikel yang diterbitkan dalam Bandung Bulletin sempat membahas kondisi Bandung ketika KAA diselenggarakan. Dalam artikel tersebut, disebut-sebutlah kebanggaan masyarakat Bandung atas terpilihnya kota mereka sebagai tuan rumah konferensi. Pemerintah Republik Indonesia menyatakan bahwa,

"The people of Bandung have taken much pride in preparing their city for the A. A. Conference. Though not offering luxury, they have earned praise for the good taste shown in the amenities they have provided" (Anonim, 24 April 1955: 16).

"Masyarakat Bandung sangat bangga dalam mempersiapkan kota mereka untuk Konferensi A. A. Meskipun tidak menawarkan kemewahan, mereka telah mendapatkan pujian untuk selera yang baik yang ditunjukkan dalam fasilitas yang mereka berikan".

Pernyataan di atas menunjukkan bahwa Bandung telah didesain sedemikian rupa untuk menciptakan kenyamanan dan keamanan bagi para peserta konferensi.

Sebelum pelaksanaan KAA, Bandung sebenarnya telah memiliki fasilitas yang lengkap untuk sebuah pertemuan berskala internasional seperti gedung yang megah dan besar, hotel yang representatif, hingga akomodasi pendukung yang dinilai sangat baik (Santoso, Januari 1956: 18). Kemudian menjelang KAA, berbagai perbaikan infrastruktur dilakukan atas perintah Presidan Soekarno (Abdulgani, April-Mei 1965: 17). Perbaikan infrastruktur ini dilatarbelakangi oleh kesan-kesan buruk para delegasi yang hadir dalam Konferensi Bogor seperti aliran air yang tidak lancar, tidak adanya fasilitas yang memadai, dan sebagainya. Bahkan beberapa pers Barat menyebut Indonesia dengan sebutan "a land of beggars" atau negerinya para pengemis hanya karena buruknya pelayanan di Konferensi Bogor (Abdulgani, April-Mei 1965:17). Karenanya, banyak fasilitas umum yang diperbaiki dan didekorasi ulang. Fasilitas yang tampak remeh seperti gantungan untuk jas pun kemudian diadakan di hotel-hotel hingga rumah yang menjadi tempat penginapan para peserta konferensi. Kota Bandung juga menawarkan kelengkapan kuliner lokal selama penyelenggaraan konferensi. Namun bagi para peserta konferensi yang ingin menikmati kuliner dari luar negeri, rupanya tersedia pula di kota ini. Pemerintah Indonesia bekerjasama dengan para panitia 
konferensi telah mengimpor kuliner tertentu seperti Madras curry, Arab nuts, hingga kuliner Eropa. Kemudian di dalam restoran-restoran besar di Bandung, sajian kuliner juga dilengkapi dengan berbagai pertunjukan seperti tari tradisional, drama, hingga musik tradisional.

Pengaturan lalu lintas di Bandung pun tidak dapat diabaikan dalam pembahasan ini. Pemerintah Kota Bandung melibatkan berbagai elemen masyarakat untuk mengatur lalu lintas. Pada jalan raya yang dilalui oleh para peserta konferensi, maka Pemerintah Kota Bandung memutuskan untuk menutup jalan tersebut untuk masyarakat dan kendaraan umum. Polisi khusus, para peserta gerakan kepanduan atau Pramuka, hingga para pemuda pemudi dari berbagai sekolah dilibatkan untuk mengatur kelancaran lalu lintas ini (Anonim, 24 April 1955:16). Mereka melakukan pengecekan secara berkala terhadap setiap kendaraan yang masuk ke sekitar wilayah pelaksanaan konferensi, untuk memastikan bahwa kendaraan yang masuk adalah yang memiliki kepentingan terhadap Konferensi Bandung. Sementara mengenai para pejalan kaki, mereka tetap memiliki haknya untuk berjalan di titik-titik penyelenggaraan konferensi.

Selama KAA diselenggarakan, berbagai pameran turut diselenggarakan. Pameran batik tradisional hingga barang-barang kerajinan hasil seni kriya masyarakat Bandung turut dipamerkan dan dijual. Masyarakat hingga institusi publik pun turut terlibat dalam pameran ini. Sekolah-sekolah Tionghoa di Kota Bandung misalnya, mereka mengadakan pameran mengenai lukisan China (Chinese Paintings) (Anonim, 24 April 1955:17). Pameran ini secara tidak langsung juga menjadi bagian dari diplomasi kebudayaan untuk mengenalkan kebudayaan lokal dan nasional kepada para peserta konferensi.

Hal lain yang tidak kalah penting untuk disoroti mengenai kondisi Bandung selama penyelenggaraan KAA adalah keamanan kota, mengingat gerombolan Darul Islam/Tentara Islam Indonesia (DI/TII) yang masih terus bergerak. Beruntungnya, Pemerintah Pusat, Pemerintah Kota Bandung, dibantu dengan elemen masyarakat berhasil mengendalikan keamanan Kota Bandung dan sekitarnya. Hal ini jelas sekali disebutkan oleh Roeslan Abdulgani (2011:151) bahwa “...tidak ada satu insiden atau 
gangguan keamanan yang terjadi selama konperensi A-A berjalan. Hormat kita kepada seluruh aparat keamanan kita!"

Keberhasilan Pemerintah mendesain Kota Bandung sebagai tuan rumah konferensi menjadikan nama Bandung naik daun. Bandung kini menjadi kota simbol dari perlawanan terhadap segala bentuk penjajahan. Kebanggaan akan kebesaran kota ini juga dirasakan oleh masyarakatnya. Para negarawan pun menunjukkan kebanggaannya pada Kota Bandung selama penyelenggaraan konferensi. Abdulgani (2011:160) menyatakan bahwa,

“...dan berbahagialah Kota Bandung, yang telah berhasil memobilisir kekuatan rakyat dan masyarakat kita untuk menciptakan suasana yang memungkinkan suksesnya Konperensi A-A”.

Melalui KAA, Bandung telah menjadi kota yang cukup mendunia. Ketenarannya sebagai kota yang mempertemukan berbagai bangsa tidak hanya terjadi sekali saja pada saat KAA, melainkan masih berlanjut hingga satu dasawarsa selanjutnya.

\section{Pembangunan dan Modernitas Bandung pasca-KAA}

Konferensi Asia Afrika (KAA) tahun 1955 telah mengembalikan citra Bandung sebagai sebuah kota modern. Konferensi ini juga telah mendorong Bandung menjadi "kota politik global" (global political city) yang menjadi tempat bagi berbagai pertemuan politik internasional dalam konteks diplomasi pascakolonial, meskipun di kota ini tidak terdapat kantor perwakilan negara-negara lain. Dengan demikian, posisi Bandung pun semakin meningkat di hadapan masyarakat internasional. Banyak pihak mendatangi kota ini, mulai dari para pemimpin atau perwakilan negara lain maupun wisatawan.

Merespons antusiasme masyarakat internasional pada Kota Bandung, berbagai perbaikan infrastruktur pun dilakukan. Perbaikan infrastruktur ini juga mendapat dukungan penuh dari Jakarta. Presiden Soekarno kemudian memerintahkan berbagai institusi untuk membantu Kota Bandung agar layak dikunjungi oleh masyarakat internasional, baik untuk konferensi maupun tujuan lain seperti wisata. 
Pembangunan yang cukup massif juga didorong oleh julukan-julukan yang diberikan pada kota kembang ini, sehingga Bandung menjadi sangat dikenal di level internasional. Nehru bahkan menyebut Bandung sebagai "the capital of Asia and Africa" atau ibukota Asia dan Afrika (Abdulgani, April-Mei 1965: 26). Secara khusus, Kota Bandung “...dihormati dan didjadikan sumber ilham bagi pedjoang-pedjoang Asia Afrika untuk kemerdekaan, keadilan, dan kemakmuran" (Abdulgani, April-Mei 1965: 25).

Bandung yang dibangun menjadi kota modern menuntut perbaikan dan pembangunan infrastruktur telekomunikasi. Menjelang KAA 1955 dilaksanakan, saluran komunikasi Bandung-Jakarta dipasang. Pasca-KAA, pemasangan dan perbaikan infrastruktur ini cukup sering dilakukan. Pada tahun 1956, Bandung menjadi pusat telekomunikasi Indonesia ke negara-negara luar. Ketika Presiden Soekarno mengadakan perjalanan ke luar negeri yang pertama, maka dibuka saluran telepon radio Bandung dengan Moskow dan Tiongkok (Soewardi dan Djajasoempena, peny., 1965: 134). Kemudian untuk mendukung Bandung sebagai kota yang layak menyelenggarakan konferensi besar, Pemerintah membuka saluran telepon radio secara internasional dengan beberapa negara seperti Hongaria, Vietnam, dan sebagainya.

Selain telekomunikasi, Kota Bandung juga difasilitasi dengan pariwisata. Sebelumnya, penting untuk diketahui bahwa pariwisata menjadi unsur yang tidak terpisahkan dari penyelenggaraan konferensi internasional. Selain sebagai sarana relaksasi bagi para peserta konferensi, sektor pariwisata juga dapat menjadi media diplomasi informal antara para peserta konferensi. Karenanya, Pemerintah Daerah Jawa Barat berupaya semaksimal mungkin mengelola sektor pariwisata di Bandung. PascaKAA hingga 1957, hanya ada beberapa kota yang memungkinkan untuk didatangi wisatawan asing. Kota-kota ini antara lain Bandung, Medan, Bali, Yogyakarta, dan Jakarta (Futtro, 2012:24).

Sebagai bentuk keseriusan mengelola pariwisata, maka pada 1957 Pemerintah Daerah Jawa Barat membentuk Dewan Pariwisata Indonesia Daerah (DEPARI Daerah), yang salah satunya mencakup DEPARI Daerah Tingkat II Bandung (Soewardi dan Djajasoempena, peny., 1965: 141). Hotel-hotel yang berada di Bandung juga 
ditingkatkan kualitas pelayanannya, sehingga menjadi hotel dan restoran. Hal ini tidak lain untuk memberikan kenyamanan bagi masyarakat internasional yang datang ke Bandung. Kemudian, tempat-tempat wisata mulai dari wisata alam hingga museum pun tidak luput dari perhatian Pemerintah. Apalagi, hampir setiap konferensi dilaksanakan terdapat kegiatan post-conference tour (Soewardi dan Djajasoempena, peny., 1965: 146).

Kesiapan Kota Bandung sebagai kota yang berskala internasional juga didukung dari sisi perekonomian. Sebenarnya, perekonomian Bandung sempat melemah akibat massifnya pemberontakan oleh DI/TII. Namun seiring berjalannya waktu, perekonomian Kota Bandung kembali pulih terutama di pusat kota. Pada 1957, terdapat lima puluh toko yang dibangun di berbagai sudut Kota Bandung. Rata-rata, tokoh-toko ini dimiliki oleh pengusaha asing (Achdian, ed., 2020:147). Terdapat pula beberapa pengusaha lokal, meskipun jumlahnya tidak sebanyak para pengusaha asing.

Secara umum, Bandung tumbuh menjadi salah satu kota industri terbesar di Jawa dengan berbagai jenis industri mulai dari industri tekstil, farmasi, hingga makanan (Anonim, 14 Juni 1963:247). Pertumbuhan industri ini juga mendapat perhatian dari pemerintah pusat. Industri tekstil misalnya, diperhatikan secara penuh karena Bandung juga menjadi salah satu pemasok ulat sutra untuk industri tekstil di kota-kota lainnya. Dukungan ini dibuktikan dengan pendirian Balai Penelitian Tekstil yang selain bertujuan untuk meningkatkan kualitas produksi tekstil, juga untuk mendidik masyarakat yang ingin mengembangkan industri ini (Muin, Mei 1965:23).

Kota Bandung juga diwarnai dengan toko-toko kecil yang menjual kerajinan tangan seperti kalung dari kerang atau hasil kriya lainnya. Selain itu, Bandung juga menjadi pusat produksi kerajinan keramik (gerabah) di Jawa Barat. Produksi berbagai kerajinan ini diharapkan dapat menjadi cinderamata bagi para peserta konferensi ataupun wisatawan yang datang. Tampaknya, ada harapan besar dari masyarakat lokal bahwa citra Bandung yang baik di mata internasional dapat memberi dampak positif bagi perekonomian mereka.

Selain menawarkan kenyamanan dari sisi infrastruktur telekomunikasi hingga perekonomian, Bandung juga terus mengalami peningkatan kualitas dari sisi 
pendidikan. Sebelumnya, pada 1957 telah dibangun pusat pelatihan dan peningkatan kualitas guru. Ialah Science Teaching Centre, yang infrastrukturnya didukung oleh Inggris di bawah naungan Colombo Plan (Bamboo Used for Science Teaching, 26 November 1957:5). Kemudian pada 1962, sebuah pusat penelitian bernama The Asian Regional Institute for School Building Research juga didirikan di kota ini (Research Centre in Bandung, 22 November 1962:5). Pusat penelitian yang didirikan dengan dukungan United Nations Educational, Scientific, and Cultural Organization (UNESCO) dan bekerjasama dengan United Nations Economic Comission for Asia and Far East ini ditujukan untuk melayani kebutuhan pengembangan gedung pendidikan di Asia dan Oseania. Terdapat pula pusat penelitian yang sama di Khartoum (Sudan) dan Mexico City (Many UNESCO Achievement Mark Past Years Work, 1 Februari 1965:7). Untuk mendukung Bandung sebagai kota wisata, didirikan pula institusi pendidikan yang bergerak di bidang pariwisata seperti Akademi Industri Pariwisata (AKTRIPA) yang didirikan pada 1962 dan Akademi Bahasa Asing (ABA) yang didirikan satu tahun kemudian. Institusi pendidikan ini diharapkan mampu melahirkan orang-orang yang memiliiki kemampuan mengelola sektor pariwisata.

Kemudian, institusi pendidikan yang sebelumnya hanya diperuntukkan bagi anak-anak yang memiliki fisik normal, kini ditingkatkan dengan membangun sekolahsekolah khusus penyandang disabilitas. Khusus di Bandung, hingga 1963 telah dibangun beberapa sekolah untuk penyandang tunarungu, tunanetra, tunawicara, hingga anak-anak yang memiliki kelainan mental (Anonim, 1963:45). Membahas para penyandang disabilitas, Bandung juga dibangun menjadi kota yang inklusif. Khusus bagi penyandang tunanetra, Pemerintah bahkan menyediakan institusi tersendiri dengan nama "Rumah Buta" yang sebelumnya dikelola oleh swasta. Tidak hanya menyediakan ruang bagi para penyandang disabilitas, Pemerintah Pusat bekerjasama dengan Pemerintah Provinsi Jawa Barat dan Pemerintah Kota Bandung juga membuka kelas untuk para pengajar sekolah-sekolah disabilitas. Dengan demikian, terjadi keseimbangan antara ketersediaan guru dengan jumlah siswa penyandang disabilitas.

Ketenaran Bandung pasca-KAA kemudian menjadi lahan investasi bagi Pemerintah Indonesia. Adapun investasi yang dimaksud adalah dengan membangun 
reaktor atom di beberapa wilayah, termasuk di Bandung. Proyek ini jelas tidak dapat dilepaskan dari kontestasi politik saat itu, dimana Perang Dingin telah mendorong banyak negara untuk mengembangkan atom. Di Bandung, Pemerintah mengembangkan proyek reaktor Triga Mark II, bersamaan dengan pembangunan proyek sejenis di daerah Serpong (Anonim, Juni 1964:26). Pembangunan reaktor ini juga bertujuan meningkatkan kemajuan di daerah Bandung, berkaca pada kemajuan di kota-kota di Eropa yang memiliki reaktor di dalamnya. Di Eropa maupun Amerika, kota-kota yang memiliki reaktor bertransformasi menjadi kota yang ramai, terkenal, menarik minat masyarakat, serta memiliki peluang tinggi untuk pertumbuhan dan perkembangan ekonomi (Anonim, Juni 1964:26). Padahal, Bandung pada tahun 1964 sudah menjadi kota yang sangat ramai dan terkenal (Anonim, Juni 1964:26).

Berbagai pembangunan yang terjadi dalam satu dasawarsa pasca-KAA telah mendorong Bandung menjadi kota yang kental dengan modernitas. Gedung yang megah, hotel-hotel yang nyaman, aktivitas ekonomi yang beragam, hingga keindahan kota menjadi ciri yang melekat pada Kota Bandung. Modernitas ini kemudian menjadi bekal bagi Bandung untuk menjadi kota yang dinilai layak menyelenggarakan berbagai momen diplomatik di level internasional.

\section{Dari "Kota Lautan Api”" Menjadi "Kota Konferensi Internasional"}

Konferensi Asia Afrika (KAA) sebagai sebuah peristiwa diplomatik menjadi penanda sebuah "era baru" bagi Kota Bandung. Paling tidak, Bandung sejak 1955 telah dikenal di kancah regional Asia-Afrika, meskipun pada faktanya kemudian dikenal luas di tataran internasional. Bandung secara tidak langsung menjadi kota politik global (global political city) yang menghubungkan aktor-aktor politik internasional. "Aktor politik" disini tidak hanya berupa diplomat atau pejabat negara, tetapi juga para mahasiswa, wartawan, atau tokoh-tokoh lainnya yang turut mempengaruhi kondisi politik internasional pada tahun 1950-1960an. Konektivitas global ini sangat terlihat hingga akhir pemerintahan Presiden Soekarno. Hal ini dikarenakan banyaknya konferensi internasional yang diselenggarakan di Bandung pasca pelaksanaan KAA. Secara khusus, KAA juga telah membentuk citra baru bagi Kota Bandung, yakni dari 
"kota lautan api" menjadi "kota konferensi internasional" yang didukung dengan segala fasilitas dan infrastruktur yang ada di kota ini.

Lalu, konferensi apa saja yang pernah diselenggarakan di Bandung? Sebagai kota yang mewarisi semangat persatuan dan perjuangan negara-negara Asia dan Afrika, maka Bandung menjadi kota yang cukup penting bagi berbagai "konferensi turunan" dari KAA. Sekitar satu tahun pasca-pelaksanaan KAA misalnya, Bandung kembali menjadi muara bagi semangat persatuan Asia-Afrika melalui penyelenggaraan Konferensi Mahasiswa Asia Afrika (KMAA). Hal ini mengacu pada pernyataan yang tertulis dalam Mimbar Penerangan, bahwa "baru-baru ini di kota Priangan, jaitu Bandung, ditengah-tengah alam nan indah, serta sedjuk dan njaman hawanja, telah dilangsungkan suatu konferensi dari wakil-wakil mahasiswa di Asia-Afrika" (Anonim, Juli 1956:442). Konferensi ini awalnya diselenggarakan pada 30 Mei sampai 4 Juni 1956, namun kemudian diperpanjang hingga 7 Juni 1956 (KMAA Diperpandjang Sampai Tgl. 7/6, 4 Juni 1956:1).

Secara umum, konferensi ini membahas kerja sama hingga peran mahasiswa Asia Afrika, terutama dalam berkontribusi di bidang pendidikan hingga memecahkan masalah-masalah sosial seperti diskriminasi rasial. Dalam konferensi ini, diselenggarakan pula sebuah pawai yang dikuti oleh seluruh delegasi. Pawai ini diselenggarakan di Kota Bandung pula, sehingga masyarakat Bandung dapat turut menyaksikannya (Gambar 1). Secara tidak langsung, pawai ini juga mengingatkan kembali pada "Bandung Walk" yang diselenggarakan saat KAA 1955. Karenanya setelah terkenal di kalangan negarawan, Bandung kemudian terkenal di kalangan mahasiswa.

Tidak lama setelah KMAA usai, Bandung kembali disibukkan dengan konferensi akbar. Tepatnya pada 8-19 Oktober 1956, Bandung menjadi tuan rumah bagi Konferensi FAO (Food and Agriculture Organization) ke-III untuk Asia dan Timur Jauh (Soesmojo, Desember 1956:782). Pada saat itu, Bandung jelas telah sangat siap menerima konferensi besar - sebagaimana dalam menjadi tuan rumah beberapa konferensi sebelumnya. Dalam sebuah artikel yang diterbitkan dalam Mimbar Penerangan, Soesmojo (Desember 1956) menuliskan, 
"Kota Bandung ... kini membuktikan kesanggupannja untuk menampung penjelenggaraan konferensi internasional... Kota Bandung memang memiliki segala fasiliteit untuk kepentingan comfort tamu-tamu luar negeri dan dalam negeri. Bagi tamu luar negeri, hawa nan sedjuk dan njaman, tidaklah merupakan perbedaan djauh dengan iklim negara aslinja. Bagi tamu dalam negeri, hawa dan segar dan sehat itu, merupakan verfrissing bagi kesehatan rochani dan djasmani. Apa jang tidak ada di kota ini? Semua serba ada. Mau ontjommilo, kelom geulis, tetek bengek aneka warna, ada! Mau pemandangan indah, sebentar pergi ke luar kota, sampailah sudah. Mau belandja, sebentar angkat kaki dari hotel atau tempat penginapan, sampailah sudah di toko-toko besar. Mau nonton, mau ini, mau itu, dan... serba mudah" (hlm. 783).

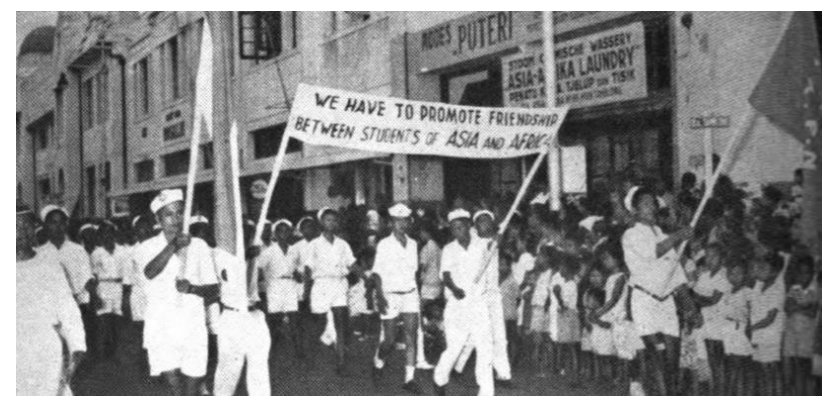

Gambar 1. Kegiatan Pawai Dalam Rangkaian Acara KMAA di Kota Bandung (Sumber: Mimbar Penerangan, Juli 1956, hlm. 446)

Beberapa tempat pun menjadi ramai dengan kehadiran delegasi dari 23 negara. Gedung Merdeka menjadi tempat untuk membuka konferensi pada tanggal 8 Oktober 1956. Sementara itu, kegiatan utama konferensi dilakukan di Gedung Direktorat Adjudan Djenderal, yang oleh Pemerintah direnovasi dan diberi tanda "FAO Conference Building”. Kelayakan gedung ini sebagai pusat pelaksanaan konferensi juga didukung dengan pemandangan Gunung Tangkuban Perahu yang dapat dilihat dari bagian atas gedung.

Kemudian, beberapa hotel seperti Hotel Preanger dan Savoy Homann menjadi tempat penginapan bagi para delegasi serta diramaikan oleh para fotografer. Jalanan Kota Bandung juga menjadi lebih ramai, terutama dipenuhi oleh mobil para panitia dan delegasi konferensi, sehingga lalu lintas umum di sekitar pelaksanaan konferensi dibatasi untuk sementara. Namun, masyarakat Bandung masih dapat menyaksikan 
kemeriahan konferensi ini, dengan berjalan kaki atau menunggu di sekitar jalan utama yang dilalui oleh para peserta konferensi. Setiap mobil panitia ditandai dengan papan bertuliskan "FAO Conference", sementara mobil delegasi ditandai dengan simbol yang mewakili negara masing-masing. Konferensi ini, menurut Soesmojo (Desember 1956:788) telah “...membikin Bandung lebih terkenal dan populair di dunia internasional. Kota Bandung ditempatkan ditengah-tengah kesibukan konferensi, jang mendapat perhatian ratu dunia dan mata dunia”. Bahkan, Soesmojo (Desember 1956:782) juga menuliskan, "penduduk Kota Bandung boleh merasa bangga, kalau kotanja untuk sekian kali dipilih mendjadi kota konferensi”.

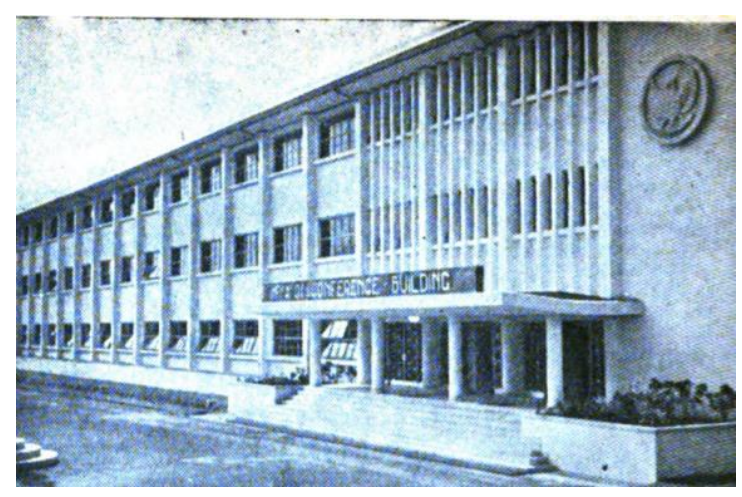

Gambar 2. Gedung yang digunakan untuk FAO Conference 1956 di Bandung (Sumber: Mimbar Penerangan, Desember 1956, hlm. 786)

Usai menjadi tuan rumah bagi FAO Conference, Bandung kemudian menjadi tempat diskusi mengenai perikanan darat. Ialah IPFC (International Pacific Fishery Council) Conference yang diselenggarakan pada 13 sampai 29 Mei 1957 (Soewardi dan Djajasoempena, peny., 1965:135). Konferensi ini menjadi salah satu momen penting bagi Indonesia untuk memperbaiki pengelolaan sektor perikanan darat. Pada tahun yang sama, Bandung juga menjadi tempat pelaksanaan The Twenty-Ninth Conference of the Federation of Indonesian-Eurasian.

Bandung dimeriahkan kembali sebagai bagian dari konferensi besar pada tahun 1963. Tepatnya pada bulan Maret, Bandung (dan Jakarta) menjadi tuan rumah PATA (Pacific Area Travel Association) Conference, sebuah konferensi internasional dalam bidang pariwisata. Dalam konferensi ini, Bandung ambil bagian menjadi tuan rumah 
bagi kegiatan PATA Promotion Workshop di Gedung Merdeka. Dampak yang sangat nyata dari konferensi ini adalah perubahan lima hotel di Bandung menjadi hotel pariwisata yang bertaraf internasional. Hotel-hotel ini antara lain Hotel Savoy Homann, Hotel Preanger, Hotel Istana, Hotel Kumala, serta Hotel Panghegar. Selain menjadi tempat penginapan, hotel-hotel tersebut juga dilengkapi dengan fasilitas lain seperti restoran, sehingga pengunjung dapat menikmati kuliner lokal maupun kuliner dari negara lain di tempat ini.

Satu bulan kemudian pada April 1963, Bandung kembali mendapat kehormatan untuk menerima tamu internasional melalui Konferensi Wartawan Asia Afrika (KWAA). Konferensi ini diselenggarakan untuk menyatukan dan mempertemukan para wartawan dari dua benua ini. Kegiatan utama konferensi sebenarnya diselenggarakan di Jakarta, dengan dihadiri tokoh-tokoh nasional seperti Presiden Soekarno, Nyonya Hartini Soekarno, Perdana Menteri Djuanda, Menteri Luar Negeri Soebandrio, dan lainlain (Anonim, Juni 1963:53). Meskipun seluruh acara utama konferensi dilaksanakan di Jakarta, namun panitia memilih Bandung sebagai lokasi penutupan konferensi. Resepsi penutupan ini tepatnya diselenggarakan pada malam hari, tanggal 30 April 1963 di Gedung Asia Afrika (Anonim, Juni 1963:60).

Kemudian keesokan harinya, diadakan jamuan terakhir di Hotel Homann yang diiikuti dengan berbagai hiburan tradisional. Tentu menjadi sebuah kehormatan bagi Kota Bandung untuk kembali memeriahkan solidaritas Asia-Afrika. Urgensi Bandung dalam rangkaian acara KWAA juga ditegaskan oleh Roeslan Abdulgani, yang dalam pidato penutupan konferensi menyatakan bahwa “...Bandung adalah Asia-Afrika bentuk ketjil..." (Anonim, Juni 1963:60-61). Oleh karena itu, keberadaan Bandung tentu tidak dapat diabaikan begitu saja.

Hingga tahun 1965 - satu dasawarsa pasca-KAA diselenggarakan - Bandung masih memiliki tempat tersendiri dalam benak bangsa-bangsa di Asia dan Afrika. Hal ini dibuktikan dengan diselenggarakannya Konferensi Islam Asia Afrika (KIAA) di Bandung, tepatnya pada Maret 1965. Konferensi ini dihadiri oleh 33 negara, dimana delegasi yang dikirimkan merepresentasikan komunitas Islam di negara masing-masing. Jauh sebelum konferensi ini dilaksanakan, pada Juni 1964, konferensi pendahuluan 
telah diselenggarakan di Jakarta dan menghasilkan resolusi mengenai upaya bersama untuk membentuk Organisasi Islam Asia Afrika (Chisaan dalam Lindsay dan Liem, peny., 2012:289).

Berbagai konferensi internasional yang telah diselenggarakan di Bandung menambah nilai jual Kota Bandung di kancah internasional. Tidak heran jika tokohtokoh dari berbagai negara hampir selalu memasukkan Kota Bandung ke dalam daftar kunjungan mereka ketika berada di Indonesia. Kunjungan ke Bandung ini tidak jarang juga menjadi bagian dari "diplomasi informal" antara tokoh-tokoh negara lain dengan Pemerintah Indonesia. Nikita Kruschev, Perdana Menteri Uni Soviet, memasukkan Bandung dalam daftar kunjungannya ke Indonesia pada 1960 (Soviet Premier Arrives in Bandung, 21 Februari 1960:16).

Kemudian, Perdana Menteri Aljazair Ferhat Abbas pernah bertandang ke Bandung dalam kunjungannya ke Indonesia pada Januari 1961 (Anonim, Januari 1961:32). Ferhat Abbas bahkan memiliki tujuan khusus ke Bandung, yakni untuk melihat gedung-gedung yang pernah menjadi tempat penyelenggaraan KAA enam tahun sebelumnya. Selain itu, ia juga mendapatkan kesempatan khusus untuk berpidato di hadapan mahasiswa Universitas Padjajaran.

Dalam pidatonya yang berlangsung sekitar empat puluh menit itu, PM Ferhat Abbas sempat memuji posisi Bandung dengan mengatakan “...Bandung nanti akan mendjadi terindah dari segala ibukota, jakni ibukota kemerdekaan dunia mereka yang tertindas" (Anonim, Januari 1961:40). Kunjungan ini juga dilakukan dalam rangka membangkitkan kembali solidaritas Asia Afrika agar mendukung perjuangan kemerdekaan Aljazair.

Kemudian pasca penyelenggaraan Games of New Emerging Forces (GANEFO) pada 1963 misalnya, tamu-tamu dari berbagai negara seperti Korea Utara, Kamboja, Arab Saudi, Polandia, dan lain-lain mengadakan tour atau sesi wisata ke berbagai kota termasuk Bandung (Departemen Penerangan, Desember 1963:37). Sementara itu, rombongan dari Republik Rakyat Tiongkok (RRT) secara khusus bahkan menyambangi Kota Bandung untuk bertemu dengan masyarakat lokal disana (Departemen Penerangan, Desember 1963:37). 
Posisi Bandung sebagai tuan rumah berbagai konferensi hingga tempat pertemuan para aktor politik internasional pasca-KAA memang patut dibanggakan. Namun, dibalik kemeriahan ini, Bandung tidak jauh berbeda dengan kota-kota besar lainnya seperti Jakarta atau Surabaya. Di balik kemegahan Bandung dengan segala pembangunan dan keramaiannya selama menjadi tuan rumah berbagai konferensi, tidak dapat dipungkiri bahwa perkembangan ini juga diikuti dengan dampak negatif. Dampak negatif ini berupa masalah sosial hingga ekonomi yang mengakar di Kota Bandung akibat ketidakmampuan beberapa kelompok masyarakat mengakses ruang-ruang modernitas yang telah tersedia.

\section{Sisi Lain Bandung: Masalah-masalah Sosial Hingga Ekonomi}

Sebagai kota yang mendapat tempat tersendiri dalam percaturan politik internasional pasca-KAA, pembangunan dan modernitas memang sudah semestinya menjadi bagian dari kehidupan Bandung. Ditambah posisinya sebagai kota politik global dan kota konferensi internasional, Bandung selalu digambarkan sebagai kota yang megah dan modern. Namun, harus disadari bahwa kota ini juga menghadapi masalah-masalah sosial, moralitas, hingga ekonomi yang sangat bertolakbelakang dengan pencapaiannya sebagai kota yang modern pasca-KAA.

Sebagaimana pada umumnya, modernitas sebuah kota akan selalu diikuti dengan perubahan sosial di dalamnya. Perubahan ini tidak hanya menimbulkan dampak positif, tetapi juga dampak negatif. Begitu pula dengan Bandung, imajinasi mengenai modernitas Bandung sebagai ruang politik global hingga kota konferensi juga diikuti dengan berbagai permasalahan di dalam kota.

Tidak lama setelah KAA usai, Kota Bandung kembali menjadi sorotan media lokal hingga media internasional akibat isu Hospitality Committee. Kuat dugaan bahwa Panitia KAA mendatangkan beberapa perempuan penghibur untuk menemani delegasi dari berbagai negara yang datang ke konferensi akbar tersebut. Sontak, hal ini mengundang protes dari berbagai pihak. Kontroversi yang sama juga terjadi di kalangan pers. Pers oposisi seperti Indonesia Raya dan Pedoman misalnya menjadikan isu Hospitality Committee sebagai headline (Anwar dikutip oleh Utama, 2017:152). 
Protes yang dilayangkan berbagai pihak tidak hanya menyayangkan adanya isu Hospitality Committee sebagai "kecelakaan" bagi moral bangsa Indonesia. Bagaimanapun, banyak pula pihak yang menyayangkan isu tersebut dengan alasan telah menodai citra baik Kota Bandung. Nurdjannah (Juni 1955:2) menyatakan bahwa,

"Kota Bandung dengan adanya peristiwa ini semakin terkenal bukan saja dengan dunia kepelisirannya yang terkenal itu, tapi juga akan terkenal dengan adanya hidangan istimewa untuk para tamu yang telah mendapat "kehormatan" yang sangat berlebihan."

Nurdjannah (Juni 1955: 5) juga menilai bahwa "kehormatan" berupa perempuan penghibur yang diberikan kepada tamu-tamu dari negara lainnya, telah menyinggung perasaan para perempuan di Bandung secara khusus, serta masyarakat Indonesia secara umum. Meskipun pada kenyataannya, banyak pula pihak yang memaklumkan pemberitaan tersebut dengan anggapan bahwa adanya perempuan penghibur dalam sebuah konferensi internasional ataupun pertemuan diplomatik yang besar adalah sesuatu yang wajar.

Kota Bandung memang memiliki sisi kelam berkaitan dengan prostitusi. Di tengah gegap gempita pelaksanaan berbagai konferensi, beberapa pusat prostitusi terus beroperasi di kota ini. Hal ini dapat dibuktikan dari penangkapan perempuanperempuan penghibur yang dilakukan oleh aparat keamanan secara berkala. Surat kabar Algemeen Indisch Dagblad: De Preangerbode misalnya, memberitakan bahwa polisi telah menangkap tujuh belas perempuan penghibur di Bandung (Razzia Door de Zedenpolitie, 29 Juni 1956). Para perempuan ini kemudian dibawa ke dinas atau panti sosial untuk menjalani pemulihan moral dan psikologis.

Fenomena yang sama juga dijumpai di banyak sudut Kota Bandung hingga tahun-tahun berikutnya. Rata-rata, prostitusi ini menjadi jalan pintas bagi para perempuan yang kesulitan memenuhi kebutuhan hidupnya. Apalagi, semakin dikenalnya Bandung sebagai kota penyelenggara konferensi di kancah internasional menjadikan arus modernisasi semakin kuat di kota ini. Sementara itu, harus diakui bahwa untuk mengakses ruang-ruang modernisasi juga membutuhkan modal yang tinggi. Mereka yang memiliki kemampuan dan modal hidup yang terbatas, terjebak 
pada permasalahan sosial sekaligus degradasi moral seperti prostitusi. Fenomena prostitusi yang menjamur di Bandung ini kemudian mengakibatkan maraknya kaum muda yang mengalami penyakit kelamin (Gonorhea). Secara lebih lanjut, Dr. Satrijo yang pernah menjabat sebagai Menteri Kesehatan RI menilai bahwa penyakit ini dapat memicu kebutaan. Dr. Satrijo (April 1963:257) menyatakan bahwa per tahun 1959, dua puluh persen penyakit kebutaan di wilayah Bandung disebabkan oleh faktor penyakit kelamin.

Selain disibukkan dengan isu prostitusi, Bandung yang pada pertengahan 1950an tengah disorot oleh dunia internasional juga disibukkan dengan memuncaknya gerakan DI/TII. Van Dijk (1981:102) menyebutkan bahwa pada 1957, gerakan ini memiliki 13.000 pasukan di Jawa Barat. Hal ini menjadikan beberapa wilayah - terutama di luar Kota Bandung - menjadi tidak aman, mengingat kekerasan, perampokan, hingga kerusuhan sering kali terjadi. Menurut Van Dijk (1981), ratusan ribu orang di Jawa Barat bahkan harus mengungsi oleh peristiwa ini. Diantara para pengungsi tersebut, rupanya banyak yang memilih untuk mengamankan diri ke Kota Bandung. Akibatnya, terjadi peningkatan jumlah penduduk di dalam kota dalam waktu yang cukup cepat.

Sayangnya, kenyamanan dan kemewahan Bandung tidak dapat dinikmati para pengungsi ini. Harga tanah dan properti yang mahal misalnya, tentu tidak bisa dijangkau oleh mereka yang datang sebagai pengungsi. Akibatnya, banyak terjadi kasus penggunaan tanah milik orang lain tanpa izin. Permukiman ilegal berdiri di berbagai sudut kota, bertolak belakang dengan wajah Bandung sebagai kota yang indah, bersih, nyaman, dan modern. Tidak jarang kerusuhan juga terjadi di wilayah permukiman ilegal ini, terutama ketika Pemerintah kota Bandung hendak menertibkan permukiman. Karenanya, Pemerintah Kota Bandung harus berurusan dengan para pemukim ilegal yang tidak mudah untuk diatasi.

Masalah trauma akibat DI/TII ini bukan menjadi satu-satunya alasan bagi urbanisasi masyarakat ke pusat Kota Bandung. Masalah-masalah lain seperti kemiskinan di pinggiran kota, keterbatasan lapangan pekerjaan, hingga keterbatasan fasilitas pendidikan di wilayah pinggiran menyebabkan banyaknya masyarakat yang pindah ke pusat kota. Ada imajinasi yang kuat dalam benak masyarakat bahwa dengan 
berhijrah ke Bandung, mereka akan dapat mengakses pekerjaan, pendidikan, hingga hidup dalam ruang-ruang modernitas yang tersedia.

Akibatnya, terjadi kenaikan jumlah penduduk yang cukup drastis terutama pada 1960 dimana penduduk meningkat hingga 1.028.245 jiwa dari sebelumnya yang berjumlah 986.880 jiwa pada 1959 (Achdian, ed., 2020:148). Meskipun Bandung telah menjadi salah satu kota industri terbesar di Jawa, namun peningkatan jumlah penduduk di pusat kota ini jelas mengganggu jalannya kehidupan sosial dan ekonomi. Industrialisasi yang disusul dengan ledakan jumlah penduduk justru tidak diikuti dengan kemajuan sumber daya masyarakatnya. Akibatnya, muncul kemiskinan di beberapa titik permukiman liar yang bahkan masyarakatnya kesulitan untuk membeli bahan makanan pokok.

Bangunan-bangunan kumuh juga mulai memadati Kota Bandung. Hal ini jelas sangat mengganggu citra Bandung sebagai Kota Konferensi Internasional. Akibatnya, petugas keamanan di Kota Bandung secara rutin melakukan patroli untuk menertibkan kebersihan di sekitaran kota. Jika terdapat bangunan yang menyalahi regulasi kebersihan, maka petugas keamanan tidak segan-segan untuk memberikan sanksi. Dalam sebuah berita yang dimuat di The Iraq Times misalnya, disebutkan bahwa sebuah hotel, sebuah pabrik dengan tinggi bangunan enam lantai, dan tujuh puluh bangunan pertokoan ditutup untuk sementara karena mengabaikan aturan kebersihan (Untidy Buildings Closed Down, 14 Januari 1960:6). Bangunan-bangunan tersebut dinilai baru dapat dibuka kembali jika pemiliknya sudah membersihkan dan merapikan semuanya.

Permukiman padat dan lingkungan yang kumuh mengantarkan Bandung pada masalah-masalah lainnya. Krisis air bersih - masalah klasik yang terjadi di berbagai kota - juga pernah dialami masyarakat Bandung. Pada saat yang sama, Bandung juga harus menghadapi gelombang pandemi influenza. Gelombang penyebaran influenza sebenarnya bukanlah hal baru, sebab hal ini juga pernah terjadi ketika masih masa kolonial Hindia Belanda. Namun, kembali mewabahnya influenza di beberapa wilayah di Indonesia - termasuk Bandung - tidak dapat diabaikan. Kasus influenza ini meningkat tajam pada 1957, dimana per pertengahan Juni terjadi peningkatan dari 2158 kasus menjadi 3837 kasus (6 Noodpoliklinieken: Stijging influenza..., 24 Juni 1957). 
Merespons peningkatan kasus influenza ini, Pemerintah Kota Bandung kemudian memperpanjang jam kerja klinik. Pada sore hari, klinik-klinik ini harus melayani pemeriksaaan dan pemberian obat kepada masyarakat yang terkonfirmasi influenza. Bagi masyarakat yang kurang mampu, maka obat-obatan tersebut diberikan secara gratis.

Meskipun menghadapi berbagai permasalahan, Bandung terus membangun diri. Pembangunan di berbagai sudut kota terus menerus dilakukan, hingga pada akhirnya biaya pembangunan membengkak pada tahun 1960an. Pada 1964 misalnya, keuangan Bandung mengalami defisit hingga sekitar tiga ratus juta rupiah sehingga Pemerintah Pusat di Jakarta harus memberikan subsidi untuk kepentingan pembangunan. Hal ini jelas sangat berlawanan dengan arus pariwisata dan bisnis yang sebenarnya cukup berkembang di kota ini. Selain biaya pembangunan yang membengkak, fasilitas di beberapa sudut kota pun tidak dikelola dengan baik. Jalan Asia Afrika misalnya - yang sangat terkenal di kalangan tamu maupun wisatawan asing - kekurangan lampu penerangan.

Kondisi Kota Bandung semakin keruh menjelang berakhirnya masa pemerintahan Presiden Soekarno. Pada 1960an, ketika Presiden Soekarno terus menerus menyerukan revolusi Indonesia, masyarakat Jawa Barat justru menyerukan gerakan kontra revolusi. Gerakan ini merupakan bentuk protes dan perlawanan dari masyarakat terhadap kekacauan ekonomi pada saat itu. Kekacauan ekonomi kemudian menimbulkan sentimen terhadap etnis Tionghoa yang memang memegang perekonomian di berbagai sektor. Timbul kecurigaan dari masyarakat dan golongan mahasiswa bahwa etnis Tionghoa-lah yang telah menyebabkan mereka mengalami kesulitan ekonomi. Apalagi, di Kota Bandung sendiri memang cukup banyak pengusaha Tionghoa yang menggelar bisnisnya. Kondisi ini juga diperparah dengan adanya keyakinan yang tertanam pada bangsa Indonesia secara umum dimana etnis Tionghoa dianggap sebagai orang asing, meskipun banyak dari Tionghoa tersebut yang merupakan Tionghoa peranakan. Akibatnya, terjadi demonstrasi besar-besaran di Jawa Barat pada 1963. Di Kota Bandung, peristiwa ini terjadi pada 10 Mei 1963, sehingga disebut dengan "Peristiwa 10 Mei 1963" (Departemen Penerangan, Mei 1963:16). Para 
mahasiswa sebenarnya juga terlibat dalam peristiwa bersejarah ini. Aksi ini kemudian diikuti dengan penjarahan dan perusakan fasilitas umum hingga perusahaan-perusahaan milik Tionghoa di Kota Bandung (Departemen Penerangan, Mei 1963:10). Sebenarnya, kerusuhan dan penjarahan ini masih berlanjut pada hari-hari selanjutnya. Di Braga salah satu pusat perekonomian Kota Bandung - tidak satupun toko-toko milik Tionghoa yang lolos dari penjarahan (De Braga en Dode Straat..., 21 Mei 1963).

Selain pusat perekonomian, permukiman Tionghoa juga tidak luput dari aksi penjarahan. Rumah-rumah dirusak, tidak peduli bahwa etnis Tionghoa juga telah berkontribusi dalam membangun perekonomian di Bandung. Akibat dari kerusuhan ini, Pemerintah menangkap beberapa orang yang diduga menjadi dalang dari peristiwa tersebut. Terdapat enam terdakwa yang merupakan mahasiswa dari ITB (Institut Teknologi Bandung) dan Universitas Padjajaran yang dinilai menjadi provokator dalam peristiwa bersejarah ini (Anwar, 2006:346). Keenam mahasiswa tersebut dijatuhi hukuman penjara, ditambah dengan bukti bahwa mereka dinilai telah melakukan kekerasan terhadap etnis Tionghoa bahkan sebelum peristiwa 10 Mei 1963 berlangsung.

Presiden Soekarno melalui Rapat Umum Wanita Partindo di Senayan pada 19 Mei 1963 kemudian menyatakan bahwa kerusuhan di Bandung tersebut merupakan gerakan kontra revolusi yang didalangi oleh aktivis bekas PSI, Masyumi, PRRI, juga dinilai ada unsur subversi asing (Anwar, 2006:244). Akibatnya, beberapa tokoh masyarakat yang ada di sekitar lokasi kerusuhan juga ditangkap oleh Pemerintah Pusat.

Kerusuhan kembali terjadi pada tahun 1965, sebagai buntut dari peristiwa Gerakan 30 September (G30S) yang mengakibatkan terbunuhnya beberapa jenderal. Dalam peristiwa mengerikan ini, Partai Komunis Indonesia (PKI) menjadi pihak yang dituduh sebagai dalang pembunuhan dan pemberontakan. Wieringa dan Katjasungkana (2020:31) memperjelas, bahwa tuduhan ini pun diperjelas oleh Soeharto dan loyalisnya dengan menamai gerakan ini "G30S/PKI”. Akibatnya, muncul kemarahan publik yang sangat besar sehingga terjadi penangkapan dan penggrebekan di markas-markas PKI dan organisasi yang berafiliasi dengannya.

Berbagai laporan menyebutkan bahwa ribuan pemuda menyerbu kantor PKI dan afiliasinya di Kota Bandung (Temporary Ban on Mass Organizations in Indonesia, 18 
Oktober 1965:1). Kota ini juga turut tercoreng akibat adanya isu bahwa Gerwani telah mengirim perempuan-perempuan Tasikmalaya ke prostitusi yang ada di Bandung (Pusat Penerangan, 1965:343 dikutip oleh Wieringa dan Katjasungkana, 2020:125). Isu ini seakan mengungkit kembali wajah Bandung sebagai kota yang menjadi pusat prostitusi, setelah sebelumnya pernah menjadi perbincangan di kancah internasional saat isu Hospitality Committee naik ke permukaan.

Masalah-masalah di atas hanya sebagian dari permasalahan yang terjadi di Kota Bandung. Secara umum, antara satu masalah dengan masalah yang lainnya menyebabkan dampak yang sama, yakni adanya ketimpangan baik secara sosial maupun ekonomi. Di pusat kota, di mana berbagai konferensi diselenggarakan, yang terlihat adalah modernitas dengan segala keindahannya. Namun di titik-titik tertentu dimana masyarakat tidak memiliki modal untuk mengakses modernitas di Bandung, mereka hidup dalam kemiskinan dan tingkat kesejahteraan yang rendah.

\section{PENUTUP}

Peristiwa diplomatik ternyata tidak hanya mempengaruhi kondisi politik suatu negara atau kawasan tertentu. Lebih dari itu, peristiwa diplomatik dapat mendorong perubahan dan perkembangan kota yang menjadi tuan rumahnya. Hal ini juga terjadi pada Konferensi Asia Afrika (KAA) 1955 yang ternyata mengubah citra dan kondisi Kota Bandung hingga satu dasawarsa berikutnya. Sejak 1955 hingga 1965, Bandung menjadi kota politik global yang sangat dikenal oleh para negarawan hingga aktor nonstate seperti para wartawan, penulis, dan lain-lain. Bandung kini menjadi "pusat" dari diplomasi pascakolonial Dunia Ketiga, sebab di Bandung pula terjalin komitmen solidaritas Asia Afrika hingga solidaritas antikolonialisme dan antiimperialisme.

Dikenalnya Bandung ke hampir seluruh penjuru dunia membuat kota ini menjadi salah satu kota yang sering digunakan sebagai tempat penyelenggaraan konferensi internasional. Daya tarik Bandung sebagai Kota Konferensi Internasional ini juga didukung oleh fasilitasnya yang cukup lengkap. Pasca-KAA, Pemerintah dengan segala upayanya juga melengkapi Kota Bandung dengan jaringan telekomunikasi yang terhubung ke berbagai kota penting di dunia, hingga fasilitas-fasilitas yang 
menunjukkan modernitas mulai dari rumah sakit, sekolah khusus penyandang disabilitas, reaktor nuklir, dan sebagainya sehingga kota ini dinilai layak untuk menerima tamu internasional.

Sayangnya, modernitas Bandung yang dihasilkan pasca-KAA tidak selalu diikuti oleh kemajuan masyarakat lokalnya. Kemiskinan dan berbagai masalah sosial lainnya masih membelenggu masyarakat. Modernitas ini juga membawa konsekuensi pada degradasi moral seperti dibuktikan dengan banyaknya pusat-pusat prostitusi akibat gelombang urbanisasi yang meningkat. Namun, masalah sosial, moral, dan ekonomi yang mengakar di Bandung ini sejatinya merupakan konsekuensi dari modernitas yang dicapai.

Bagaimanapun, modernitas dan masalah-masalah sosial dan ekonomi bagaikan dua sisi mata uang yang akan terus melekat dengan tingkat kesejahteraan yang sangat berlawanan. Terlepas dari masalah-masalah ini, Bandung pada periode 1955 hingga 1965 telah menorehkan sejarahnya sendiri. Apalagi, tidak banyak kota di Indonesia atau bahkan di kawasan Asia yang memiliki tempat dalam percaturan politik internasional. Kajian ini kiranya juga dapat menjadi refleksi bagi Indonesia pada abad ke-21 agar kembali membangkitkan kota-kota lokal selain Jakarta sebagai ruang di mana konektivitas global hidup, sehingga terjadi pertukaran ide, perbincangan politik, kebudayaan, dan aspek-aspek lainnya di dalam kota. Dalam jangka panjang, kota yang menjadi tempat terkoneksinya gagasan-gagasan global juga sangat mendukung agar kota menjadi aktor diplomasi (city diplomacy), sehingga diplomasi tidak hanya dilakukan di level negara atau pemerintah pusat. 


\section{DAFTAR PUSTAKA}

6 Noodpoliklinieken: Stijging influenza in Bandung. 24 Juni 1957. Algemeen Indisch Dagblad: de Preangerbode.

Abdulgani, Roeslan. 2011. The Bandung Connection: Konperensi Asia Afrika di Bandung Tahun 1955. Jakarta: Kementrian Luar Negeri Indonesia.

Abdulgani, Roeslan. April-Mei 1965. "Sedjarah Lahirnya KAA I: Mengungkap Kembali Faktor-Faktor jang Mensukseskan Bandung II”. Mimbar Indonesia. Vol 19. No. 4-5. Hlm. 11-13, 16-17, dan 25-26.

Achdian, Andi (peny.). 2020. Geliat Kota Bandung: Dari Kota Tradisional Menuju Modern. Jakarta: Bank Indonesia Institute.

Anonim. 14 Juni 1963. “A Journey Through Industrial Java”. Overseas Trading. Vol. 15. No. 11. Hlm. 247-249.

Anonim. 1963. “Kebutaan di Indonesia”. Mimbar Penerangan. Vol. 14. No. 3. Hlm. 4447.

Anonim. 24 April 1955. "Bandung During the Conference”. Bandung Bulletin. No. 9. Hlm. 16-22.

Anonim. Januari 1961. "Kundjungan Pejuang Besar Nasional Aljazair Ferhat Abbas di Indonesia". Mimbar Penerangan. Vol. 12. No. 1. Hlm. 32-41.

Anonim. Juli 1956. "Sedikit Kesan Tentang Konferensi Mahasiswa Asia Afrika di Bandung". Mimbar Penerangan. Vol. 7. No. 7. Hlm. 442-447.

Anonim. Juni 1963. “K.W.A.A. Penting bagi Perdjuangan Menentang Imperialisme dan Kolonialisme II". Mimbar Penerangan. Vol. 14. No. 2. Hlm. 53-61.

Anonim. Juni 1964. "Lenyapkan Salah Pengertian tentang Tenaga Atom". Mimbar Indonesia. Vol. 18. No. 4. Hlm. 25-28, Hlm. 34.

Anonim. Mei 1955. "Bandung: That Lovely City”. Wanita. Vol. 7. Hlm. 221-225.

ANRI. April 1955. "Artikel/Makalah Mohammad Yamin dalam Surat Kabar Merdeka Jakarta Tanggal 27 April 1955 Mengenai Asia Afrika Tuntut Irian Barat”. Inventaris Arsip Mohammad Yamin. No. 43.

ANRI. Januari 1955. "Memorandum dari S. Suryocondro kepada Duta Besar Mengenai Reaksi Pers Amerika Serikat dan Inggris terhadap Rencana Penyelenggaraan Konferensi Asia Afrika Tanggal 25 Januari 1955". Arsip Sekretariat Negara Kabinet Perdana Menteri 1950-1959. No. 2199.

Anwar, Rosihan. 2006. Soekarno, Tentara, PKI: Segitiga Kekuasaan sebelum Prahara Politik 1961-1965. Jakarta: Yayasan Obor Indonesia.

Bamboo Used for Science Teaching. 26 November 1957. The Iraq Times. Hlm. 5. 
Chisaan, Choirotun. 2012. "In Search of An Indonesian Islamic Cultural Identity, 19561965", dalam Jennifer Lindsay dan Maya H.T. Liem (peny.). Heirs to World Culture: Being Indonesia 1950-1965. Leiden: KITLV Press. HIm. 283-314.

De Braga en Dode Straat: Javanen in Actie tegen Chinezen. 21 Mei 1963. De Tijd de Maasbode.

De Freytas-Tamura, Mariko. September 2009. "Comparative Global Political Cities: Brussels and Paris", dipresentasikan dalam The 2009 Annual Meeting of The American Political Science Association. Toronto, Kanada.

Departemen Penerangan. Desember 1963. "Ganefo: Mendobrak Susunan Lama". Mimbar Penerangan. Vol. 14. No. 5. Hlm. 29-39.

Departemen Penerangan. Mei 1963. "Waspada terhadap Kontra Revolusi”. Mimbar Penerangan. Vol. 14. No. 2. Hlm. 10-17.

Futtro, Tiko Dwiantoro. 2012. "Peranan Dewan Tourisme Indonesia dalam Menunjang Pariwisata di Indonesia (1957-1965)". Skripsi. Fakultas Ilmu Pengetahuan Budaya. Universitas Indonesia.

KMAA Diperpandjang Sampai Tgl. 7/6. 4 Juni 1956. Pedoman. Hlm. 1-2.

Kuntowijoyo. 2013. Pengantar Ilmu Sejarah. Yogyakarta: Tiara Wacana.

Many UNESCO Achievement Mark Past Years Work. 1 Februari 1965. Baghdad News. Hlm. 7.

Muin, Bachtiar H.S. Mei 1965. "Home Industri Punja Peranan di dalam Ekonomi Rakjat Tersebar Luas di Masjarakat Jawa Barat". NEFO. Vol. 3. No. 14. Hlm. 23.

Nurdjannah. Juni 1955. “Terlampau Ramah Tamah!” Dunia Wanita. Vol. 7. No. 12. Hlm. 2; Hlm. 5.

Nurwulandari, Rahmia dan Kemas Ridwan Kurniawan. 2020. "Europa in de Tropen": The Colonial Tourism and Urban Culture in Bandung". Journal of Architectural Design and Urbanism. Vol. 2. No. 2. Hlm. 15-23.

Razzia Door de Zedenpolitie. 29 Juni 1956. Algemeen Indisch Dagblad: de Preangerbode.

Research Centre in Bandung. 22 November 1962. The Iraq Times. Hlm. 5.

Rusnandar, Nandang. 2010. "Sejarah Kota Bandung dari "Bergdessa" (Desa Udik) Menjadi Bandung "Heurin Ku Tangtung" (Metropolitan)". Patanjala. Vol. 2. No. 2. Hlm. 273-293.

Santoso, Rahmat. Januari 1956. "Djawatan Penerangan dalam Konferensi-Konferensi Internasional di Bandung”. Mimbar Penerangan. Vol. 7. No. 1. Hlm. 18-21. 
Satrijo. April 1962. "Menteri Kesehatan RI: Kampanje Anti Buta Pada Hari Kesehatan Sedunia”. Mimbar Penerangan. Vol. 13 No. 4. Hlm. 254-260.

Soesmojo. Desember 1956. "Goresan Kesan: Ketika Bandung Sibuk Dengan Konferensi Regional FAO Untuk Asia dan Timur Djauh". Mimbar Penerangan. Vol. 7. No. 12. Hlm. 782-788.

Soewardi, R. Odi dan R. Nana Djajasoempena. 1965. Sedjarah Perkembangan Pembangunan Daerah Djawa Barat Tahun 1945-1965. Bandung: Badan Koordinasi Pembangunan Daerah Tingkat I Jawa Barat.

Soviet Premier Arrives in Bandung. 21 Februari 1960. The Iraq Times. Hlm. 16.

Suganda, Her. 2011. Wisata Parijs van Java: Sejarah, Peradaban, Seni, Kuliner, dan Belanja. Jakarta: Kompas.

Temporary Ban on Mass Organizations in Indonesia. 18 Oktober 1965. Baghdad News. Hlm. 1.

Untidy Buildings Closed Down. 14 Januari 1960. The Iraq Times. Hlm. 6.

Utama, Wildan Sena. 2017. Konferensi Asia-Afrika 1955: Asal Usul Intelektual dan Warisannya bagi Gerakan Global Antiimperialisme. Tangerang: Marjin Kiri.

Van Dijk, C. 1981. Rebellion Under the Banner of Islam: The Darul Islam in Indonesia. Den Haag: Martinus Nijhoff.

Wieringa, Saskia E., dan Nursyahbani Katjasungkana. 2020. Propaganda dan Genosida di Indonesia: Sejarah Rekayasa Hantu 1965. Depok: Komunitas Bambu. 